\title{
INCREASING MICRO-PURITY AND DETERMINING THE EFFECTS OF THE PRODUCTION WITH AND WITHOUT VACUUM REFINING ON THE QUALITATIVE PARAMETERS OF FORGED-STEEL PIECES WITH A HIGH ALUMINIUM CONTENT
}

\author{
POVEČANJE MIKROČISTOČE IN DOLOČITEV UČINKA \\ PROIZVODNJE, Z VAKUUMSKIM RAFINIRANJEM ALI BREZ, NA \\ KVALITATIVNE PARAMETRE KOVANEGA JEKLA Z VISOKO \\ VSEBNOSTJO ALUMINIJA
}

\author{
Vladislav Kurka1, Jaroslav Pindor ${ }^{1}$, Jana Kosňovská1, Zdeněk Adolf ${ }^{2}$ \\ ${ }^{1}$ Material and metallurgical research, Ltd, Pohranicni 693/31, 70300 Ostrava-Vítkovice, Czech Republic \\ ${ }^{2}$ VŠB - Technical University of Ostrava, 17. listopadu 15/2172, 70833 Ostrava-Poruba, Czech Republic \\ vladislav.kurka@mmvyzkum.cz \\ Prejem rokopisa - received: 2014-10-13; sprejem za objavo - accepted for publication: 2015-03-24
} doi:10.17222/mit.2014.258

\begin{abstract}
The quality production technology for the WNr. 1.8504 steel was developed. The aim of the work was to achieve the required internal micro-purity and determine the effects of different production technologies on the qualitative parameters of forged-steel pieces. Firstly, polygonal ingots weighing $1600 \mathrm{~kg}$ were produced, using the metallurgical units, in a controlled-atmosphere induction-melting furnace (IF) without vacuum treatment, and in a vacuum and pressurized induction-melting furnace (VPIM) with vacuum treatment. The ingots were subsequently reshaped by open-die forging into bars with a rectangular cross-section. The effect of the ingot-production technology was evaluated by comparing the forged-steel pieces in terms of their purity, macrostructure and microstructure.

Keywords: vacuum, inclusion, aluminium, steel

Izvršen je bil razvoj kakovostne proizvodne tehnologije jekla W.Nr. 1.8504. Namen je bil doseči želeno notranjo mikročistočo in ugotoviti vpliv različnih tehnologij proizvodnje na kvalitativne parametre odkovkov. Najprej so bili izdelani poligonalni kovani ingoti z maso $1600 \mathrm{~kg}$, z uporabo naslednjih metalurških agregatov: v indukcijski talilni peči s kontrolirano atmosfero (IF) brez vakuumskega rafiniranja in v vakuumski ter indukcijski talilni peči (VPIM) s povišanim tlakom in $z$ vakuumskim rafiniranjem. Nato so bili ingoti s prostim kovanjem preoblikovani $v$ palice s pravokotnim prerezom. Vpliv tehnologije proizvodnje ingotov je bil ocenjen s primerjavo odkovkov z vidika čistosti, makro in mikrostrukture.

Ključne besede: vakuum, vključki, aluminij, jeklo
\end{abstract}

\section{INTRODUCTION}

Aluminium is primarily used in steel as a deoxidising agent as well as an alloying element. In a melt, aluminium occurs in the dissolved form, in a solid solution as aluminium metal, aluminium oxide $\mathrm{Al}_{2} \mathrm{O}_{3}$ and, in an interaction with nitrogen, also as aluminium nitride AlN. ${ }^{1}$ An increased aluminium content in steel reduces its formability due to the mechanical effect of its precipitates, and alternatively also due to its local ferrite affecting the structural state. An increased concentration of strongly ferrite generating aluminium may occur in the vicinity of dissolved AlN particles. AlN is separated in steel in the form of acicular crystals, usually on the grain borders. The quality of WNr1.8504 (hereinafter referred to as the "steel") is, with regard to its chemical composition, intended for surface nitration. Nitration is a saturation of the steel surface with nitrogen that creates hard nitrides with the alloying elements $\mathrm{Al}, \mathrm{Cr}$, Ti and V. Figure 1 shows an example of a nitrated steel layer. The process of nitration takes place at temperatures of $500{ }^{\circ} \mathrm{C}$ - $540{ }^{\circ} \mathrm{C}$ for about $50 \mathrm{~h},{ }^{2}$ when the nitrated steel layer achieves a $0.3 \mathrm{~mm}$ thickness in $30 \mathrm{~h}$, and a $0.5 \mathrm{~mm}$ thickness in $50 \mathrm{~h}$. The process depends on the temperature, pressure, chemical composition of the steel and atmospheric composition.

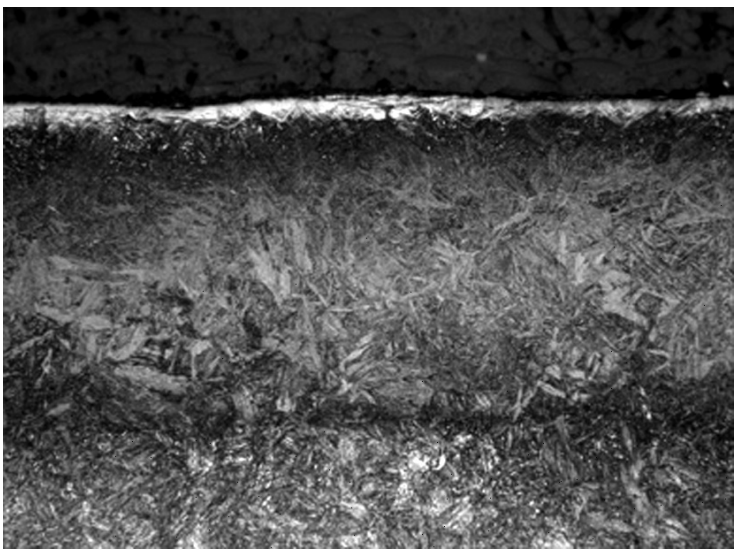

Figure 1: Example of a nitrated steel layer ${ }^{2}$

Slika 1: Primer nitrirane plasti na jeklu ${ }^{2}$ 
Nitrogen is thus an element that creates AlN nitrides with $\mathrm{Al}$ in steel, which are very hard and non-malleable. On the steel surface, it creates a hard, abrasion-resistant area. AlN nitrades inside the steel are non-malleable inclusions that impair the micro-purity of the steel. This work is concerned with the elimination of AlN inclusions from the WNr1.8504 quality steel with $0.8 \%-1.1$ $\%$ of mass fractions of high Al.

An important step in the elimination of the AlN-type inclusions with a high aluminium content from steel is the reduction of the nitrogen content to the minimum level.

\subsection{Nitrogen in steel}

Nitrogen in steel not only reacts with iron but also with other dissolved elements, forming a wide variety of compounds. These are dominated by nitrides, but carbonitrides, oxynitrides, cyanonitrides, complex binary nitrides and other phases of variable compositions can occur as well. Their existence depends on a number of factors, such as the composition of the steel, the melting method, the temperature, the pressure, the thermal treatment, etc. ${ }^{4}$ In our case, aluminium nitrides form under the liquidus temperature and re-dissolve in the steel at temperatures of $900{ }^{\circ} \mathrm{C}-1100{ }^{\circ} \mathrm{C}$, where the dissolution rate is a function of the material temperature and structure. ${ }^{5}$ Increased frequency and size of, for example, the AlN particles may lead to the generation of intercrystalline steel fractures. The effects of the elements on the solubility of nitrogen in molten iron at a temperature of $1600{ }^{\circ} \mathrm{C}$ and a nitrogen pressure of $100 \mathrm{kPa}$ are presented in Figure 2. ${ }^{4}$

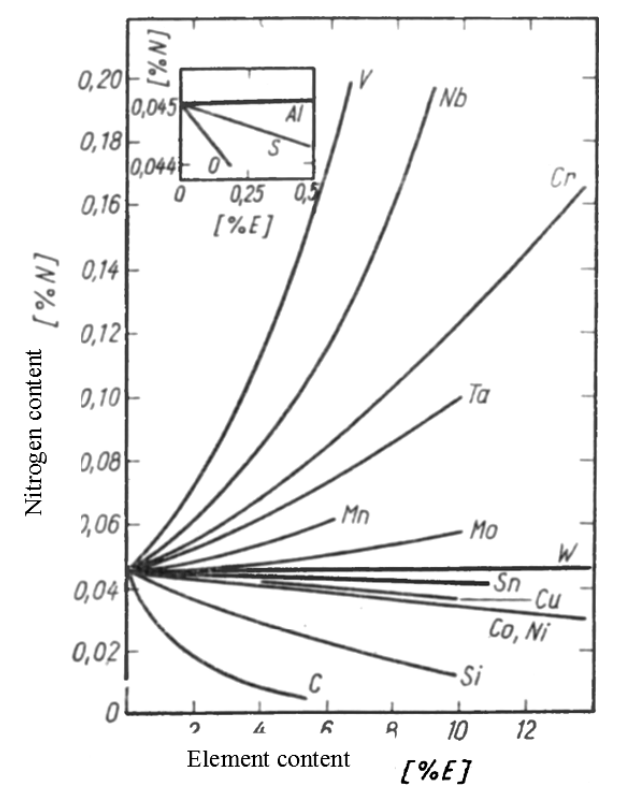

Figure 2: Effects of elements on the solubility of nitrogen in molten iron at a temperature of $1600{ }^{\circ} \mathrm{C}$ and a pressure of $100 \mathrm{kPa}^{4}$

Slika 2: Vpliv elementov na topnost dušika $\mathrm{v}$ staljenem železu pri $1600{ }^{\circ} \mathrm{C}$ in tlaku $100 \mathrm{kPa}^{4}$

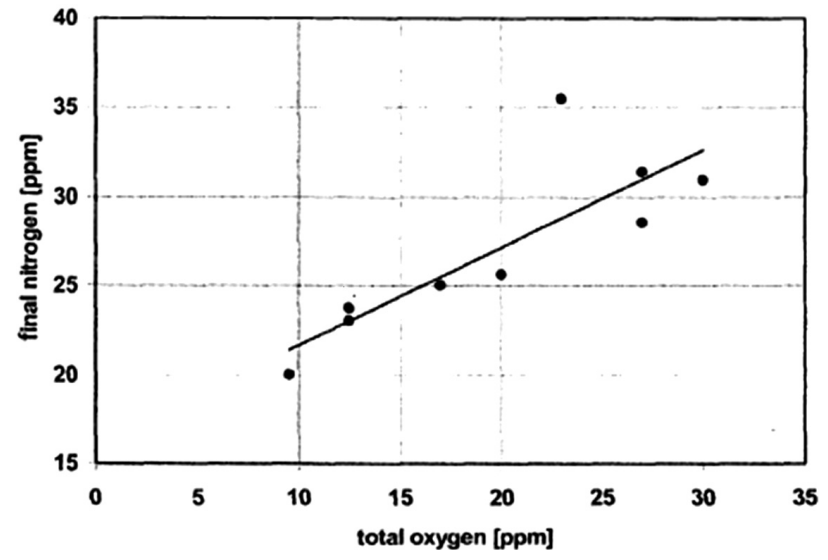

Figure 3: Nitrogen removal by tank degassing as a function of the total oxygen content ${ }^{6}$

Slika 3: Zmanjšanje vsebnosti dušika pri odstranjevanju plina v komori, kot funkcija skupne vsebnosti kisika ${ }^{6}$

Surface-active elements such as sulphur and oxygen hinder the removal of nitrogen from the molten steel during vacuuming (nitrogen diffusion in argon bubbles during bubbling) and from the vacuum above the steel surface. If reducing the nitrogen content, e.g., to a required value below $0,004 \%$ of mass fractions, very low values of sulphur and oxygen need to be ensured at the same time. See Figures $\mathbf{3}$ and $\mathbf{4}$ for a graphic illustration of this dependence. ${ }^{6}$

\subsection{Solubility of nitrogen in steel}

The solubility of nitrogen in steel and the effects of individual elements are described in detail in a previous paper. ${ }^{7}$ The transition of nitrogen in steel is governed by Sievert's law, which presupposes its atomic dissolution. The dependence of the nitrogen content in an iron melt at pressure is described with relationship (1):

$$
[\% \mathrm{~N}]_{\mathrm{Fe}}=\frac{K_{\mathrm{N}}}{f_{\mathrm{N}}} \cdot \sqrt{\left\{p_{\mathrm{N}_{2}}\right\}_{\text {rel. }}}
$$

where:

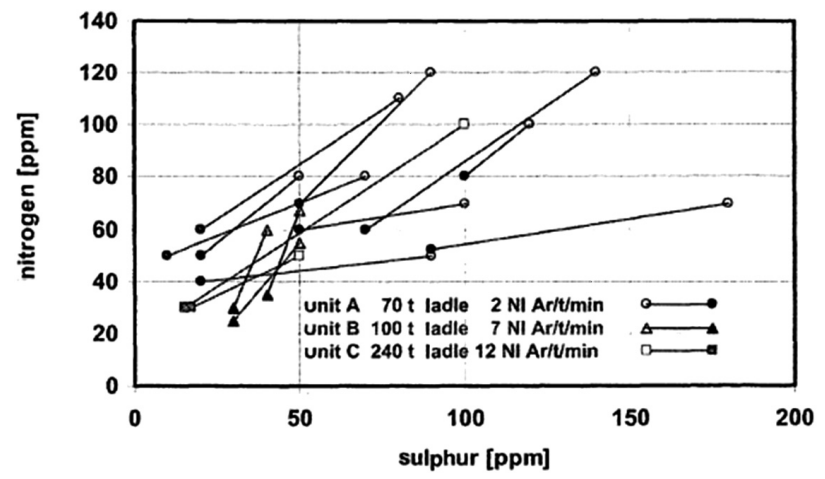

Figure 4: Nitrogen removal by tank degassing as a function of sulphur content ${ }^{6}$

Slika 4: Zmanjšanje vsebnosti dušika pri odstranjevanju plina v komori, kot funkcija skupne vsebnosti žvepla ${ }^{6}$ 
$K_{\mathrm{N}}$ is the equilibrium constant of the dissolution process (in mass fractions, $(w / \%))$ maximum,

$f_{\mathrm{N}}$ is the nitrogen activity coefficient in iron melt, ${ }^{1}$

$\left\{p_{\mathrm{N}_{2}}\right\}_{\text {rel. }}$ is the relative partial nitrogen pressure above iron melt. ${ }^{1}$

The equilibrium constant $K_{\mathrm{N}}$ expresses the nitrogen solubility in iron under standard conditions, i.e., its maximum content under a pressure of $0.1 \mathrm{MPa}\left\{p_{\mathrm{N}_{2}}\right\}_{\text {rel. }}$ $=1$ a $f_{\mathrm{N}}=1$. The temperature dependence of nitrogen solubility is expressed with Equation (2):

$$
\lg K_{\mathrm{N}}=-\frac{188}{T}-1.246=\lg [\% \mathrm{~N}]_{\mathrm{Fe}}
$$

and the adequate dependence of the reaction-free enthalpy on the temperature is expressed with relationship, Equation (3):

$$
\Delta G^{0}=3600+23.86 T(\mathrm{~J})
$$

As it is clear from Equation (2), the solubility of nitrogen at a temperature of $1600{ }^{\circ} \mathrm{C}$ is $0.045 \%$ of mass fractions, but it drops significantly when the melt solidifies. It slightly increases in iron $\gamma$, and then drops in iron $\alpha$ to approximately $0.0015 \%$ of mass fractions at $600{ }^{\circ} \mathrm{C}$.

The nitrogen solubility in steel is significantly affected by the presence of alloying elements, particularly in highly alloyed corrosion-resistant steels. The effect of alloying elements is manifested in the value of active coefficient $f_{\mathrm{N}}$ :

$$
\lg f_{\mathrm{N}}=\sum e_{\mathrm{N}}^{\mathrm{x}}[\% \mathrm{~N}]
$$

This effect can be expressed by means of interaction coefficients $e_{\mathrm{N}(1873 \mathrm{~K})}^{\mathrm{X}}$. The temperature dependence of the interaction coefficients expressing the effects of elements on the nitrogen activity was described by Chipman and, according to the author ${ }^{8}$, it is expressed with Equation (5):

$$
e_{\mathrm{N}(T, \mathrm{~K})}^{\mathrm{X}}=\left(\frac{3280}{T}-0.75\right) \cdot e_{\mathrm{N}(1873 \mathrm{~K})}^{\mathrm{X}}
$$

Therefore, the dependence of the nitrogen solubility on the temperature can be expressed with Equations (6) and (7):

$$
\begin{aligned}
& \lg [\% \mathrm{~N}]_{\text {steel }}=\lg K_{\mathrm{N}}-\lg f_{\mathrm{N}}+\frac{1}{2} \lg \left\{p_{\mathrm{N}_{2}}\right\}_{\text {rel. }} \\
& \lg [\% \mathrm{~N}]_{\text {steel }}=\left(-\frac{188}{T}-1.246\right)- \\
& -\sum\left(\frac{3280}{T}-0.75\right) \cdot e_{\mathrm{N}(1873 \mathrm{~K})}^{\mathrm{X}}+\frac{1}{2} \lg \left\{p_{\mathrm{N}_{2}}\right\}_{\text {rel. }}
\end{aligned}
$$

An improvement of the calculation is, especially for highly alloyed steels (e.g. CrNi steels) conditioned not only by the knowledge of the first values of the interaction coefficients but also of the second values and the cross-interaction coefficients, Equation (8):

$$
\begin{aligned}
& \lg [\% \mathrm{~N}]_{\text {steel }}=\lg [\% \mathrm{~N}]_{\mathrm{Fe}}-\sum e_{\mathrm{N}}^{\mathrm{X}} \cdot\left[\% \mathrm{X}^{2}\right]- \\
& -\sum r_{\mathrm{N}}^{\mathrm{X}} \cdot\left[\% \mathrm{X}^{2}\right]--\sum r_{\mathrm{N}}^{\mathrm{X}, \mathrm{Y}} \cdot[\% \mathrm{X}] \cdot[\% \mathrm{Y}]
\end{aligned}
$$

For significantly corrosion-resistant steel alloys, these values are quoted by, e.g., Z. Buzek ${ }^{8}$ in Table $\mathbf{1}$.

Table 1: Values of interaction coefficients 1, 2, and cross-interaction coefficients $^{8}$

Tabela 1: Vrednosti interakcijskih koeficientov 1, 2 in navzkrižnih koeficientov $^{8}$

\begin{tabular}{|c|c|c|c|}
\hline $\begin{array}{c}\mathrm{X}(\text { in mass } \\
\text { fractions, }(w / \%))\end{array}$ & $e_{\mathrm{N}(1873 \mathrm{~K})}^{\mathrm{X}}$ & $r_{\mathrm{N}(1873 \mathrm{~K})}^{\mathrm{X}}$ & $r_{\mathrm{N}(1873 \mathrm{~K})}^{\mathrm{X}, \mathrm{Y}}$ \\
\hline $\mathrm{Cr}$ & -0.0468 & +0.00034 & - \\
\hline $\mathrm{Nb}$ & -0.0667 & +0.00019 & $+0.00136(\mathrm{Cr}-\mathrm{Nb})$ \\
\hline $\mathrm{Mo}$ & -0.0106 & - & $+0.00002(\mathrm{Cr}-\mathrm{Mo})$ \\
\hline $\mathrm{Ni}$ & +0.0107 & - & $-0.00041(\mathrm{Cr}-\mathrm{Ni})$ \\
\hline $\mathrm{Si}$ & +0.047 & - & $-0.00149(\mathrm{Cr}-\mathrm{Si})$ \\
\hline
\end{tabular}

\subsection{Elimination of AlN from WNr1.8504 quality steel}

Elimination of the AlN inclusions from steel commenced with the evaluation of standardly produced steel with production-technology adjustments. The objective of the work was a reduction of the nitrogen content and thus the occurrence of AlN in the final product. In MMR, ingots were produced in an atmospheric induction-melting furnace (hereinafter referred to as the IF) with a nominal batch weight of $1750 \mathrm{~kg}$, and in a vacuum and pressurized induction-melting furnace (hereinafter referred to as the VPIM), in which vacuum degassing (VD) at a minimum pressure of $40 \mathrm{~Pa}$ (a), or vacuum oxygen decarburisation (VOD) can be carried out by using of an oxygen-argon nozzle.

One polygonal ingot for forging, V2A, was produced from each melt, weighing approximately $1650 \mathrm{~kg}$. With every melt, the ingot was filled from the bottom through the casting system. The ingots were forged by open-die forging into bars of the following dimensions: 140-160 $\mathrm{mm} \times 90-110 \mathrm{~mm}$.

The melts were produced and found as follows:

Melt 1 - Production of the melt in the IF with casting on an atmospheric casting bed under a protective argon atmosphere.

Melt 2 - Production of the melt in the VPIM, vacuum refined with VD, with casting on an atmospheric casting bed under a protective argon atmosphere.

Melt 3 - Production of the melt in the VPIM, vacuum refined with VD, with casting under a protective argon atmosphere in a cofferdam.

The chemical composition of the steel according to the standard $^{3}$ and the chemical compositions of the monitored and evaluated melts and forged pieces are shown in Table 2. All the melts and forged pieces featured the required standardised chemical composition. The content of nitrogen in the forged piece from Melt 1 was $0,0132 \%$ of mass fractions. This amount was reduced to the value of $0.0108 \%$ of mass fractions, 
V. KURKA et al.: INCREASING MICRO-PURITY AND DETERMINING THE EFFECTS OF THE PRODUCTION ...

Table 2: Chemical compositions of standardised ${ }^{3} \mathrm{WNr} 1.8504$, the melts and forged pieces (in mass fractions $(w / \%)$ ) Tabela 2: Kemijska sestava normiranega ${ }^{3}$ jekla WNr1.8504, taline in odkovkov (v masnih deležih $(w / \%)$ )

\begin{tabular}{|c|c|c|c|c|c|c|c|c|c|c|c|}
\hline \multicolumn{2}{|c|}{1.8504} & $\mathrm{C}$ & $\mathrm{Si}$ & $\mathrm{Mn}$ & $\mathrm{P}$ & $\mathrm{S}$ & $\mathrm{Cr}$ & $\mathrm{Al}_{\text {diss. }}$ & $\mathrm{Al}_{\text {bound }}$ & $\mathrm{Al}_{\text {total }}$ & $\mathrm{N}$ \\
\hline \multirow{2}{*}{ Standard } & $\min$ & 0.30 & 0.15 & 0.60 & - & - & 1.20 & - & - & 0.800 & - \\
\hline & $\max$ & 0.37 & 0.35 & 0.90 & 0.035 & 0.035 & 1.50 & - & - & 1.100 & - \\
\hline \multirow{2}{*}{ Melt 1} & melt & 0.33 & 0.30 & 0.81 & 0.017 & 0.006 & 1.39 & - & - & 1.20 & - \\
\hline & forged piece & 0.33 & 0.30 & 0.82 & 0.012 & 0.007 & 1.42 & 1.08 & 0.02 & 1.10 & 0.0132 \\
\hline \multirow{2}{*}{ Melt 2} & melt & 0.33 & 0.27 & 0.70 & 0.015 & 0.007 & 1.44 & - & - & 1.11 & - \\
\hline & forged piece & 0.34 & 0.26 & 0.73 & 0.011 & 0.008 & 1.45 & 1.07 & 0.02 & 1.09 & 0.0108 \\
\hline \multirow{2}{*}{ Melt 3} & melt & 0.35 & 0.24 & 0.76 & 0.018 & 0.007 & 1.47 & - & - & 0.97 & - \\
\hline & forged piece & 0.35 & 0.23 & 0.77 & 0.010 & 0.007 & 1.48 & 0.94 & 0.02 & 0.96 & 0.0108 \\
\hline
\end{tabular}

through the VD process, in the pieces forged from Melts 2 and 3 .

Elements of $\mathrm{C}, \mathrm{S}, \mathrm{N}$ were determined with the thermochemical method using equipment LECO CS 230 and LECO TCH 600. Metal samples were melted in an induction (for $\mathrm{C}$ and $\mathrm{S}$ ) or resistor (for $\mathrm{N}$ ) furnace in a gas stream. The gas was analysed for the absorption of infrared radiation (for $\mathrm{SO}_{2}$ and $\mathrm{CO}_{2}$ ) and the change in the thermal conductivity was measured (for $\mathrm{N}_{2}$ ). Elements $\mathrm{Si}, \mathrm{Mn}, \mathrm{P}, \mathrm{S}, \mathrm{Cr}$ were determined with an X-ray spectrometry apparatus, ARL ADVANT'X IntelliPower THERMOFISHER SCIENTIFIC. The method of sequential X-ray fluorescence spectrometry is based on the excitation of characteristic X-rays of the elements present in a sample using an X-ray lamp. The Al element was determined on Optima 3000SC PERKIN ELMER. The analysed sample was dissolved in acids and transferred into the solution, and then it was measured using optical emission spectrometry with inductively bounded plasma.

The pieces forged from all the melts were subjected to non-destructive ultrasound testing according to SEP 1921/84 Group 3, Class C/c. All the forged pieces fully conformed to the evaluation.

The work further presents an evaluation of the micro-purity of the pieces forged from Melts 1 to 3, according to ASTM E45-10, method A. This method classifies the inclusions by their shape and light reflec-

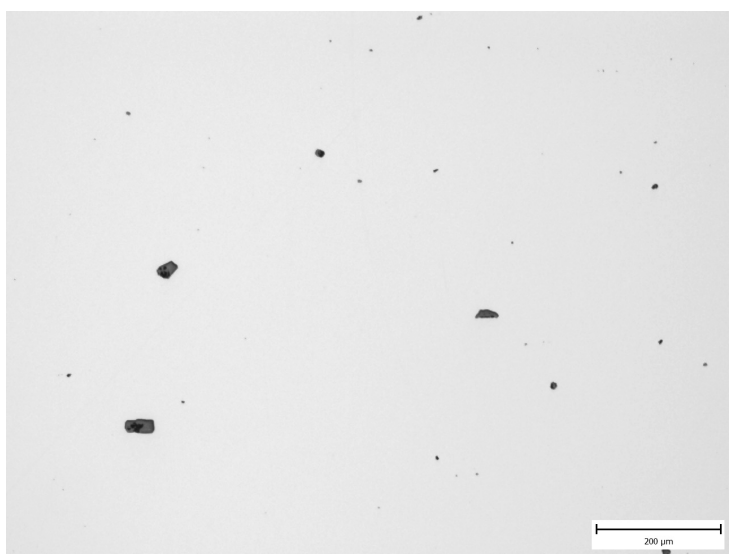

Figure 5: Non-metallic inclusions in the piece forged from Melt 1. Magnified 65x.

Slika 5: Nekovinski vključki v odkovku iz taline 1. Povečava 65×. tivity only, so their chemical composition plays no role. For the above reason, a spectral microanalysis was also performed with a scanning electron microscope JEOL JSM-5510, equipped with an energy-dispersive analyser from Oxford Instruments, with which the chemical compositions of the inclusions were determined. Last but not least, the work presents an evaluation of the forged pieces' macrostructures.

\subsection{Micro-purity of the pieces forged from Melt 1 in the IF}

First of all, micro-purity was evaluated on the pieces forged from Melt 1 in the IF. Very coarse inclusions, spot $\mathrm{D}$ (oxidic inclusions), were observed in the specimens that often exceeded the allowed limit of $12 \mu \mathrm{m}$, specified in the classification of these inclusions. The biggest inclusion achieved the size of $49 \mu \mathrm{m}$; the spot-D (oxidic) inclusions were not quite standard, i.e., globular. They featured a rather sharp-edged shape with s variable size. Then there was a smaller quantity of specimens with the inclusions arranged in lines, often in combination with sulphides that were, using the relevant standard etalon, evaluated as the $\mathrm{B}$ type - line $\mathrm{Al}_{2} \mathrm{O}_{3}$. A very low number of slightly shaped A-type inclusions were then observed in some places, exceeding the thickness of $6 \mu \mathrm{m}$ that is specified for the coarse A-type inclusions. Examples of non-metallic inclusions are shown in Figures 5 and 6;

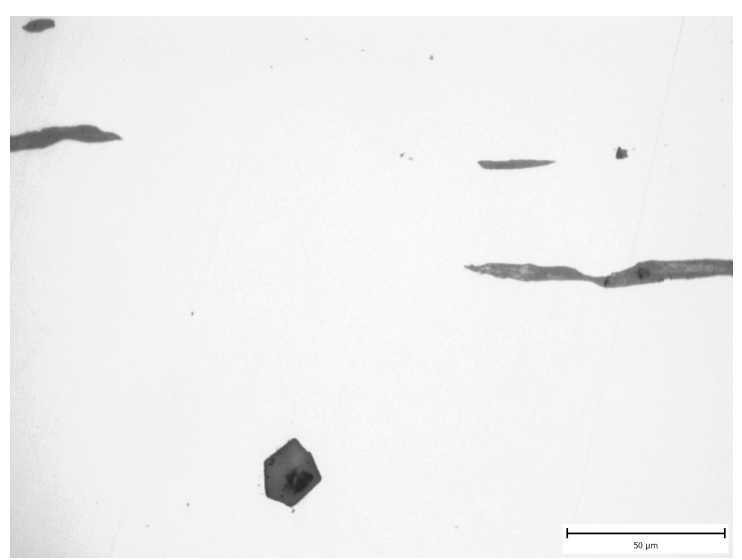

Figure 6: Non-metallic inclusions in the piece forged from Melt 1. Magnified 330x.

Slika 6: Nekovinski vključki v odkovku iz taline1. Povečava $65 \times$. 


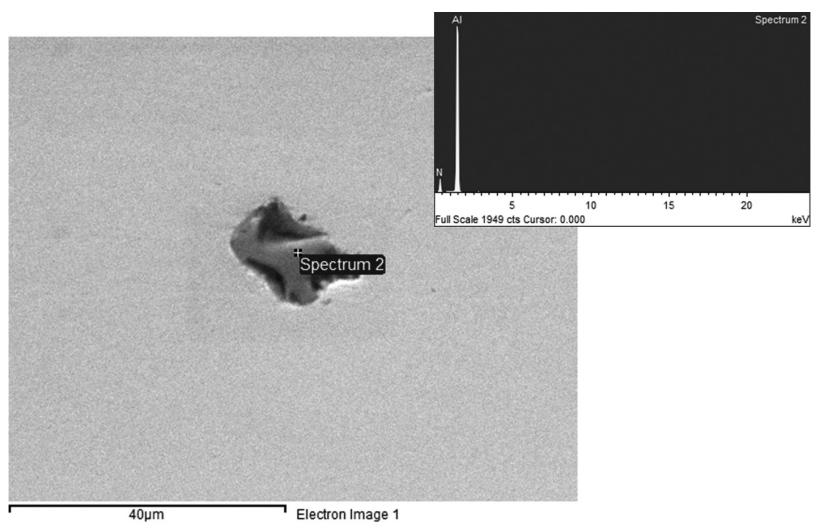

Figure 7: EDX spectrum of non-metallic AlN particles in the piece forged from Melt 1

Slika 7: EDX-spekter nekovinskih delcev AlN, v odkovku iz 1. taljenja

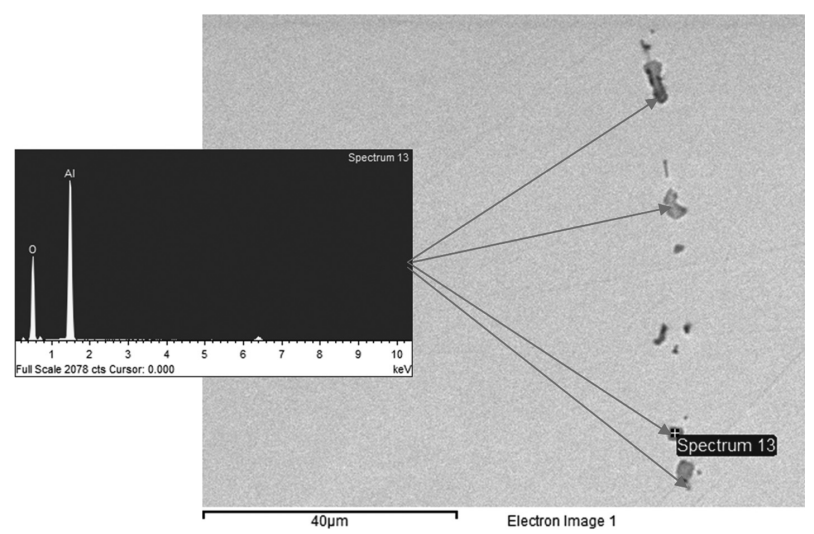

Figure 8: $\mathrm{EDX}$ spectrum of non-metallic $\mathrm{Al}_{2} \mathrm{O}_{3}$ particles in the piece forged from Melt 1

Slika 8: EDX-spekter nekovinskih delcev $\mathrm{Al}_{2} \mathrm{O}_{3}$, v odkovku iz 1 . taljenja

see Figures $\mathbf{7}$ and $\mathbf{8}$ for the chemical compositions of the most frequent inclusions.

Table 3 shows the results of the micro-purity evaluation; the table also includes the largest inclusion found in the tested metal specimens.

\subsection{Micro-purity of the pieces forged from Melt 2 in the VPIM through the VD process and casting under Ar atmosphere}

During the examination of the polished state, most often non-metallic inclusions of D- and A-type complexes were observed in the tested chains, as shown in Figures 9 and 10. Oval inclusion particles were often locally dispersed in the metallic matrix in the forged pieces, sometimes achieving a diameter of $48 \mu \mathrm{m}$. The results of the micro-purity evaluation of Melt 2 are shown in Table 3.

Locally occurring complex non-metallic particles on the tested specimen surfaces were classified into groups with the closest shape similarity. The majority of the tested inclusions were observed to be globular particles

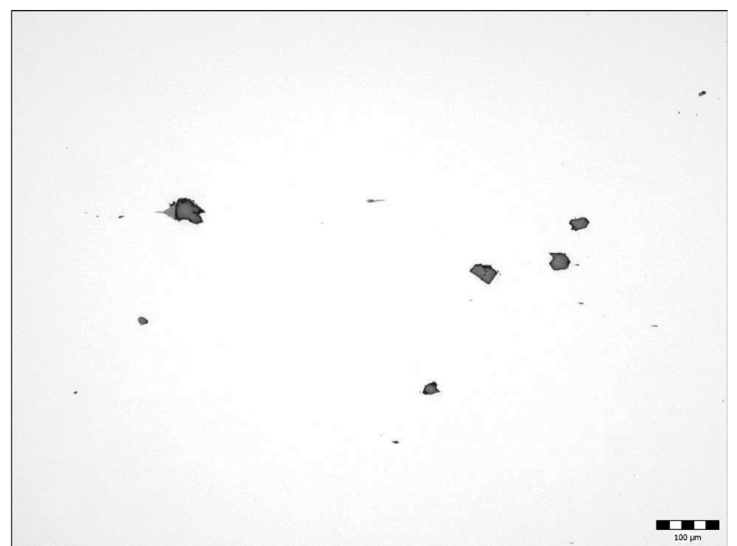

Figure 9: Non-metallic inclusions in the piece forged from Melt 2. Magnified $65 \times$.

Slika 9: Nekovinski vključki v odkovku iz taline 2. Povečava $65 \times$.

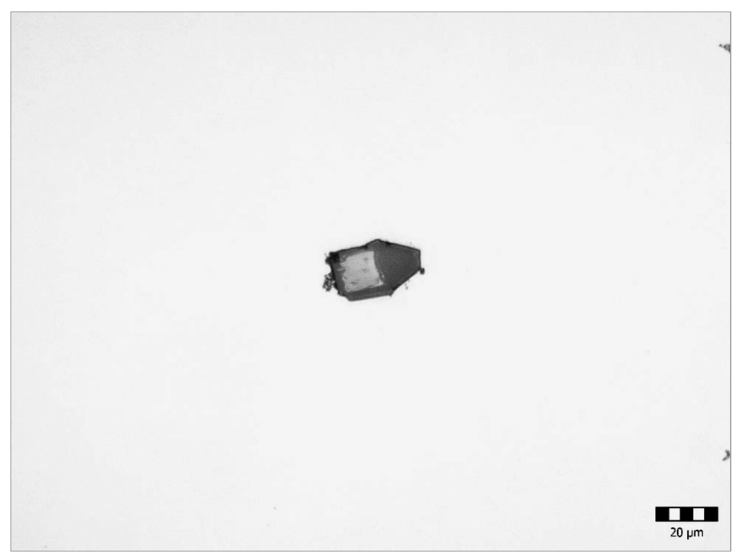

Figure 10: Non-metallic inclusions in the piece forged from Melt 2. Magnified 330x.

Slika 10: Nekovinski vključki v odkovku iz taline 2. Povečava 330x.

(D type) or elongated sulphides (A type). Small-scale tiny lines of B-type inclusions were observed in the forged-piece matrix as well.

The microanalysis detected the chemical compositions of the most frequent inclusions of the AlN type

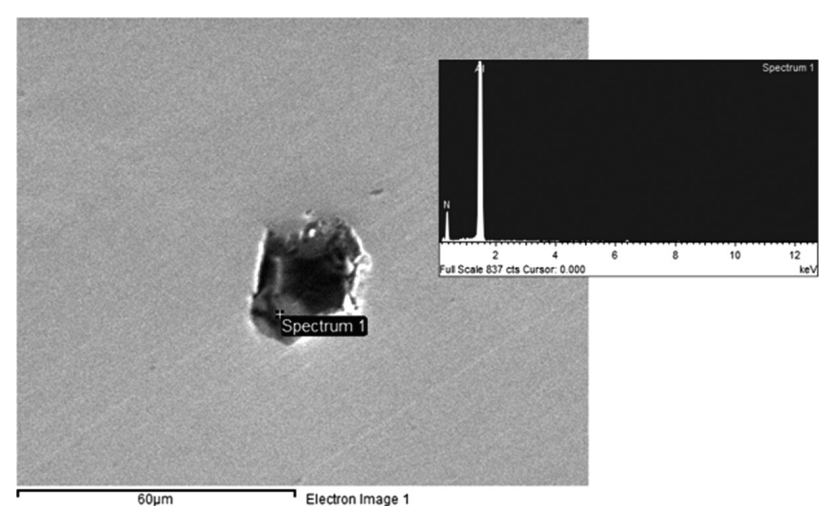

Figure 11: EDX spectrum of non-metallic AlN particles in the piece forged from Melt 2

Slika 11: EDX spekter nekovinskih delcev AlN, v odkovku iz taline 2 


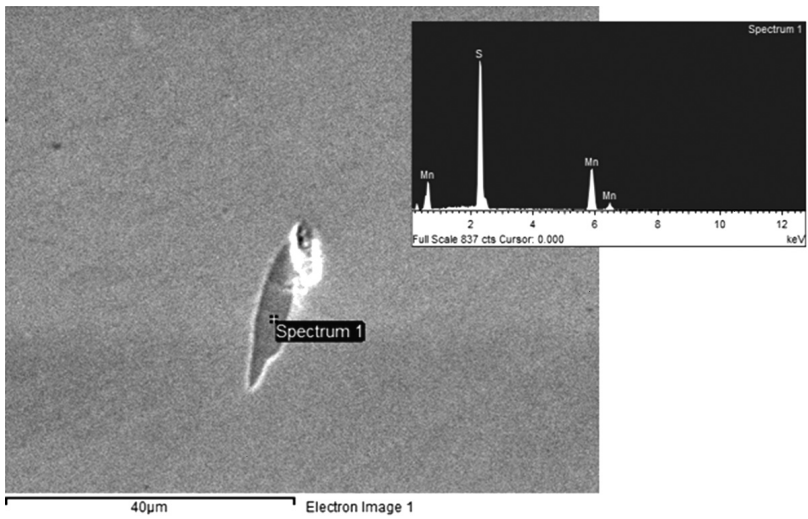

Figure 12: EDX spectrum of non-metallic MnS particles in the piece forged from Melt 2

Slika 12: EDX-spekter nekovinskih delcev MnS, v odkovku iz taline 2

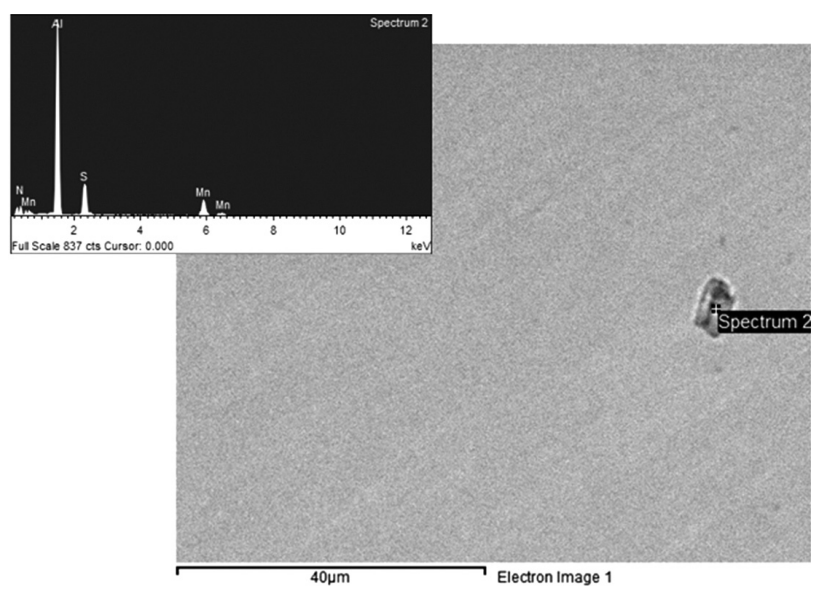

Figure 13: EDX spectrum of non-metallic AlN-MnS particles in the piece forged from Melt 2

Slika 13: EDX-spekter nekovinskih delcev AlN-MnS, v odkovku iz taline 2

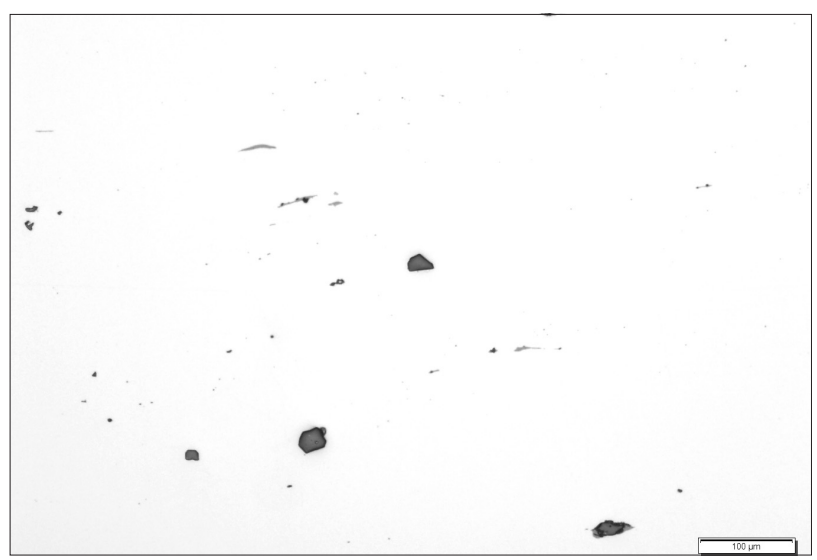

Figure 14: Non-metallic inclusions in the piece forged from Melt 3. Magnified 65×.

Slika 14: Nekovinski vključki v odkovku iz taline 3. Povečava $65 \times$.

(Figure 11), the MnS type (Figure 12), or the complex AlN-MnS type inclusions (Figure 13).

\subsection{Micro-purity of the piece forged from Melt 3 in VPIM through the VD process and casting in the cofferdam under Ar}

As in the previous cases, the presence of a high amount of coarse inclusions was detected in this forged piece; due to their shape, these inclusions were classified as D-type inclusions (oxidic inclusions). Their size significantly exceeded the admissible diameter of up to $12 \mu \mathrm{m}$ specified for the D-type inclusions. The occurrence of these inclusions was frequent and they achieved the size of up to $50 \mu \mathrm{m}$; however, their shape was not typically globular but rather angular, as shown in Figures 14 and 15. The occurrence of oxidic inclusions in a line arrangement was less frequent.

Besides the oxidic inclusions, A-type inclusions were observed in the specimen, or complexes of these inclusions, the occurrence of which was relatively frequent. The results of the non-metallic inclusion evaluation are listed in Table 3. The microanalysis revealed that, unlike in Melt 2, AlN-type inclusions were the most frequent in Melt 3, as shown in Figures 16, 17 and 18.

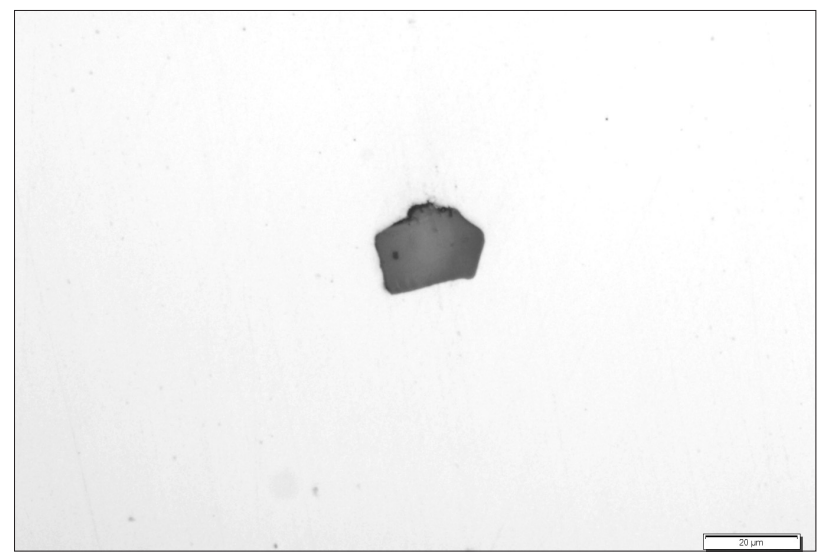

Figure 15: Non-metallic inclusions in the forged piece in Melt 3. Magnified 330x.

Slika 15: Nekovinski vključki v odkovku iz taline 3. Povečava 330x.

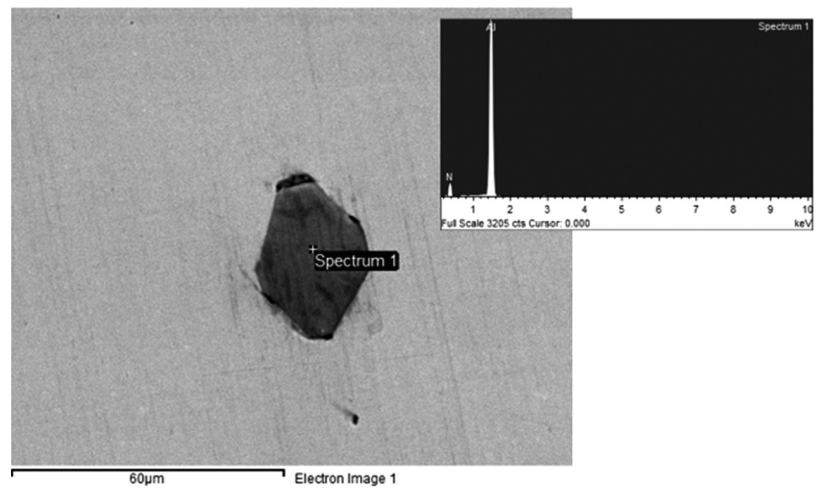

Figure 16: EDX spectrum of non-metallic AlN particles in the piece forged from Melt 3

Slika 16: EDX-spekter nekovinskih delcev AIN, v odkovku iz taline 3 


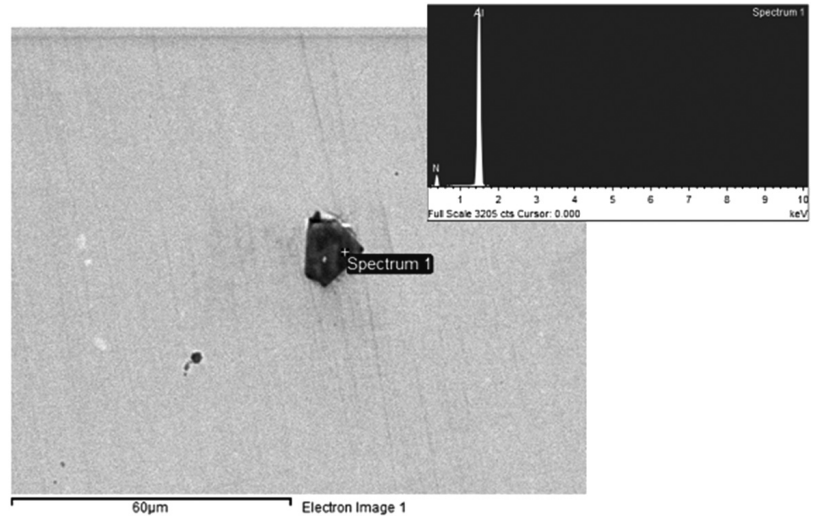

Figure 17: EDX spectrum of non-metallic AlN particles in the piece forged from Melt 3

Slika 17: EDX-spekter nekovinskih delcev AIN, v odkovku iz taline 3

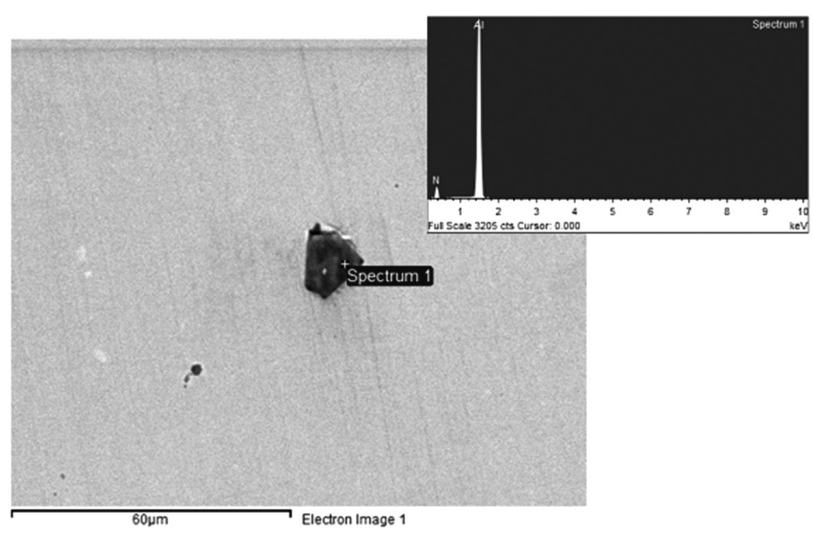

Figure 18: EDX spectrum of non-metallic AlN particles in the piece forged from Melt 3

Slika 18: EDX-spekter nekovinskih delcev AlN, v odkovku iz taline 3

\subsection{Macrostructure evaluation}

The macrostructures of the forged pieces were revealed by etching in $10 \% \mathrm{HNO}_{3}$. Unequally distributed insignificant segregations of a darker contrast were revealed in the specimen of the piece forged from Melt 1, as shown in Figure 19. More or less uniform macrostructures of the surfaces were observed for the specimens forged from Melts 2 and 3, as shown in Figures 20 and 21.

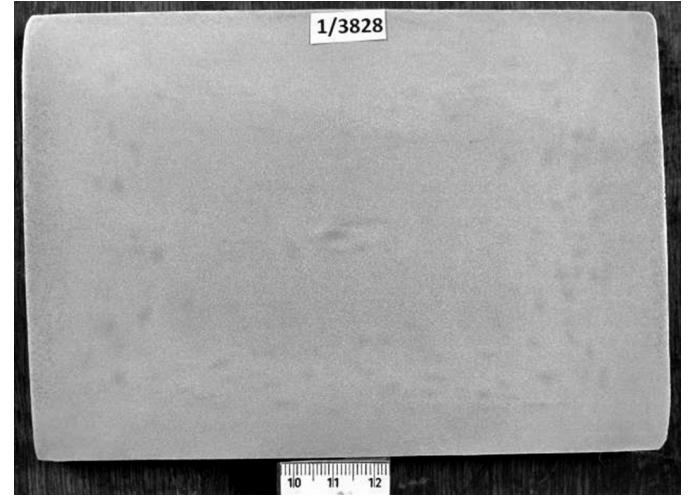

Figure 19: Macrostructure of the piece forged from Melt 1 Slika 19: Makrostruktura odkovkov iz taline 1

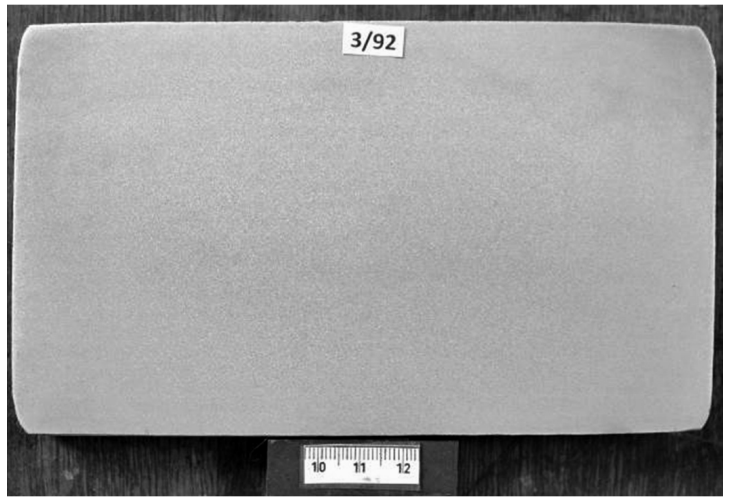

Figure 20: Macrostructure of the piece forged from Melt 2 Slika 20: Makrostruktura odkovkov iz taline 2

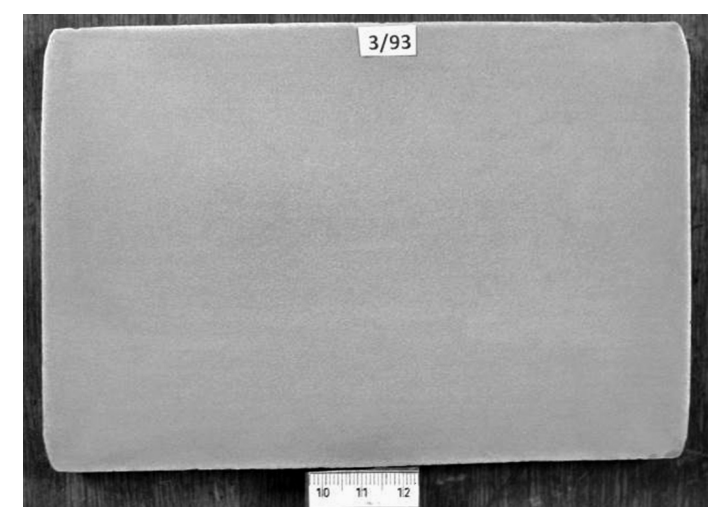

Figure 21: Macrostructure of the piece forged from Melt 3 Slika 21: Makrostruktura odkovkov iz taline 3

Table 3: Micro-purity evaluation according to the ASTM E45-10 standard, method A, and the largest D-type inclusions found in the pieces forged from Melts 1 to 3

Tabela 3: Vrednotenje mikročistoče po standardu ASTM E45-10, metoda A in največji najdeni vključki vrste D v vzorcih iz odkovkov iz taline 1 do 3

\begin{tabular}{|c|c|c|c|c|c|c|c|c|c|}
\hline \multirow{3}{*}{ Specimen } & \multicolumn{8}{|c|}{ Maximum contamination, method A } & \multirow{3}{*}{$\begin{array}{c}\text { Maximum } \\
\text { dimension of } \\
\text { D-type inclusion } \\
\mu \mathrm{m}\end{array}$} \\
\hline & \multicolumn{2}{|c|}{ Type A sulphides } & \multicolumn{2}{|c|}{ Type B aluminates } & \multicolumn{2}{|c|}{ Type C silicates } & \multicolumn{2}{|c|}{ Type D oxides } & \\
\hline & Fine & Coarse & Fine & Coarse & Fine & Coarse & Fine & Coarse & \\
\hline Melt 1 & 1 & 1 & 2 & 2 & & & 2 & 2 & 49 \\
\hline Melt 2 & 2 & 2 & 2 & 1 & - & - & 2 & 2 & 48 \\
\hline Melt 3 & 2 & 1 & 2 & - & - & - & 2 & 2 & 50 \\
\hline
\end{tabular}




\section{CONCLUSION}

The objective of the presented work was to increase the inner purity of a WNr1.8504 high-quality forged piece. For this reason, three production technologies (melts) were evaluated in this work.

As the performed analysis of the chemical compositions and non-destructive ultrasound tests indicate, the atmospheric induction furnace and the vacuum and pressurized induction-melting furnace with casting outside and inside the cofferdam are suitable for the production of this material.

However, from the macrostructural point of view, the production of melt in the atmospheric induction-melting furnace proved to be unsuitable.

With respect to the micro-purity determined with the microanalysis of the detected particles and nitrogen content in the forged pieces, none of the three technologies can be applied to achieve a reduced content of mostly AlN inclusions. The production technology for Melt 3 in the VPIM, with the VD process and the casting in the cofferdam under a protective argon atmosphere, eliminated the portion of oxidic and complex inclusions but not the AlN inclusions.

The experiments showed that vacuum degassing (VD) helps to reduce the Al content. The content of nitrogen was reduced by $0.0024 \%$ of mass fractions, from $0.0132 \%$ of mass fractions (the steel made in the IF) to $0.0108 \%$ of mass fractions (the steel made in the VPIM). Based on this fact, the authors are preparing another experiment that will eliminate the nitrogen content using vacuum oxygen decarburization (VOD) because the melt is mixed better with VOD than with VD. VOD includes a more efficient degassing process because, generally, a high oxygen content in a melt decreases the solubility of nitrogen. For this process, a newly manufactured oxygen-argon nozzle will be used.

\section{Acknowledgement}

This paper was created within Project No. LO1203 "Regional Materials Science and Technology Centre Feasibility Program" funded by the Ministry of Education, Youth and Sports of the Czech Republic.

\section{REFERENCES}

${ }^{1}$ J. Šenberger, Z. Bůžek, A. Záděra, K. Stránský, V. Kafka, Metalurgie oceli na odlitky, VUTIUM, Brno 2008, 311

${ }^{2}$ Introduction to Metallography, PACE Technologies, http://www.metallographic.com/Technical/Metallography-Intro.html, 24.09.2014

${ }^{3}$ Stahlschluessel 2007, Verlag Stahlschluessel Wegst GmbH., ver. 5.01.0000, Marbach 2007

${ }^{4}$ T. Myslivec. Fyzikálně chemické základy ocelářství, SNTL - Nakladatelství technické webliteratury, Prague 1971, 448

${ }^{5}$ J. Višek, Hodnocení růstu zrna uhlíkových a nízkolegovaných nástrojových ocelí $\mathrm{v}$ závislosti na přítomnosti AlN, http://stc.fs.cvut.cz/pdf/VisekJaroslav- 338820.pdf, 24.9.2014

${ }^{6}$ G. Stolte, Secondary Metallurgy, Verlag Stahleisen GmbH, Germany 2002, 217

${ }^{7}$ V. Kurka, Z. Adolf, J. Pindor, Producing Steel with High Nitrogen Content in Induction Melting Furnaces, European Oxygen Steelmaking Conference, Třinec, 2014

${ }^{8}$ Z. Buzek, Basic thermodynamic calculations in the steel industry, Hutnické aktuality, 29 (1988) 7 